Fifth International Conference on Sustainable Construction Materials and

Technologies. http://www.claisse.info/Proceedings.htm

\title{
UTILIZATION OF WASTE QUARRY DUST AND MARBLE POWDER IN CONCRETE
}

\author{
Dr. Maria Idrees ${ }^{1}$, Aalia Faiz ${ }^{2}$ \\ ${ }^{1}$ Assistant Professor, Department of Architectural Engineering \& Design, University \\ of Engineering \& Technology, Lahore, Pakistan, mariaidrees@uet.edu.pk \\ ${ }^{2}$ Department of Architectural Engineering \& Design, University of Engineering \& \\ Technology, Lahore, Pakistan, aliafaiz2006@googlemail.com
}

\begin{abstract}
The research focuses on the effect of using waste marble powder and quarry dust as partial sand replacement materials on concrete properties. Massive exploitation of the nonrenewable natural resources to fulfill the aggregate requirement of billions of tones each year for concrete production bears the serious risk of their gradual depletion. Therefore, concerns of aggregate material source depletion, together with the evolution of concepts of sustainable development and material conservation, leads to exploring of the effective utilization of waste materials instead of natural resources. Nine concrete mixes were prepared with Marble Powder and Quarry Dust as sand replacement materials $(12.5 \%, 25 \%, 50 \%$ separately, and 25\%, 50\% combined). The effect of the replacements on workability, tensile, compressive and flexural strengths and cost were studied. Marble Powder negatively affected the workability while Quarry Dust improved it. Strengths were improved for $12.5 \%$ replacement of both the materials but further replacement decreased the strength within acceptable limits. These waste powders improved mechanical properties (at optimum percentages) or showed acceptable strength results (at higher percentages). The replacements of natural sand by waste quarry dust and marble powder will help to resolve environmental, economic and ecological issues of concrete production and will lead towards sustainability.
\end{abstract}

Keywords: Waste materials; environmental sustainability; Marble powder, Quarry dust, strengths; concrete

\section{INTRODUCTION}

Concrete is the most widely used construction \& building material. In 2001, the global concrete production reached 12 billion tons per year (Mehta, K.P. 2001). Typically, ordinary concrete consists of cement and aggregate (coarse and fine) in the ratio of 
$20 \%$ and $80 \%$ respectively. This implies that we were, globally, using quantity of aggregates equal to 10 billion tons per annum for concrete production. 
This makes concrete one of the largest consumer of natural resources (Prabhu, G.G. 2014). It is predicted that concrete requirement will reach to 18 billion tons a year by 2050 (Monteiro, M.P. 2015).

Aggregates used in concrete are produced through open-cast mining and quarrying operations which have serious environmental and geotechnical problems such as contamination of the soil and water sources, alteration of groundwater regimes, disfigurement of the landscape, construction of tips, soil erosion, loss of flora and fauna, vegetation and soil degradation, ground instability and subsidence, and creation of dangerous voids (Manpreet Singh, 2017, Charles, K. 2017). Aggregate extraction process damages the land, making it derelict land which is incapable of beneficial use without treatment. It is not acceptable to leave large areas of land in a blighted and unusable state. Besides environmental degradation, considerable energy is consumed in mining or quarrying operations and transportation of aggregate materials. Utilization of waste or recycled materials in concrete helps in conserving natural resources, mitigates environment pollutions, reduces cost of concrete manufacturing, reduces landfill demand and its cost, and saves energy (Sarsby, R.W. 2001,Satish Chandra, 1996).

Fine aggregate, conventionally natural sand, constitutes up to $30 \%$ of the volume of concrete, which means around 4 billion tons sand is required to meet annual demand of concrete production. Although large number of sand deposits may exist worldwide but sources with sand suitable for concrete production are limited; some deposits contain undesirable quantities of silt and clay, organic impurities and unsuitable gradation, etc. Also, as these finite resources are shrinking with time, cost of sand is increasing and its availability decreasing.

Because of limited suitable sand resources in Pakistan, use of alternate materials in concrete production is much needed necessity. Various sand deposits in Pakistan include Lawrencepur and Qiblabandi in Attock, Durrani in Peshawar, Ravi in Lahore, Chenab in Multan, Ghazi in Tarbela, Wadd in Quetta and Bolari in Karachi. Sand in northern part of the country is coarser as compared to that of central and southern parts because natural flow of water is from North to South which transports finer sand to the south. Generally, coarser sand from Lawrencepur (northern region) is accepted for use in concrete which makes any project in central and south parts of the country cost intensive. All the mentioned sources of sand are finer than ASTM gradation limits except Qiblabandi and Bolari sands. Also, all the sands are poorly graded (SP) and Wadd sand source also contain clay and silt (SP-SM). Concrete produced with Ghazi, Ravi and Chanab sands has compressive strength below 3000 psi which is not desirable for concreting works (Gauhar Sabih, 2011). Ravi sand is generally fine and contains relatively higher percentage by mass of clay/silt and organic impurities and readily reacts with alkalis released by ordinary Portland cement after acquiring water (Naveed Ahsan, 1997).

Estimated marble reserves in the world are in excess of 15 billion cubic meters and its numerous processing units exist in more than 50 countries worldwide (Onargan et al., 2006; Çetin, 2003). Marble is a polished stone that is extracted through quarrying and processed into blocks and is very vital for mining economy of countries. The extraction, cutting, shaping and polishing operation of marble produces 30 to $40 \%$ waste marble in the form of powder and marble slurry. Dumping of huge quantity of waste marble 
powder requires considerable vacant land and is a critical environmental issue. Therefore, re-evaluation of this waste material will be environmentally and financially beneficial (Alyamaç and Ince, 2007). Pakistan possess more than 300 billion tones (approx.) marble and onyx reserves (TDAP, 2010). Marble processing units exist in Karachi in Sindh; Mansehra, Mardan and Peshawar in Khyber-Pakhtunkhwa; Mohmand Agency, Khyber Agency and Bajur Agency in FATA; and Quetta, Loralai and Lasbela in Balochistan (TDAP, 2010). Pakistan is using primitive mining techniques and locally fabricated machinery for this purpose. The material wastage ratio in Pakistan is relatively high, which reaches up to 73\% against the standard quarry wastage in the world i.e. 50\% of the gross produce (APMIA, 2018). This quarry wastage can also be converted to powder form for using in concrete. Similarly, quarry dust is produced in abundance in Pakistan at aggregate crushing plants such as Sargodha, Sakhi Sarwar, Margalla sites which can be as partial alternative to sand in concrete.

Research on use of waste marble powder and quarry dust in concrete is on the go worldwide. Priyatham, B. P. R. V. S. et al. (2017), found that compressive strength and split cylinder tensile strength increased when quarry dust was substituted for sand up to $30 \%$ along with $10 \%$ marble powder as cement substitute. Siong Kang Lim et al (2017) showed that quarry dust utilization as sand replacement in Lightweight Foamed Concrete improves its compressive strength $\&$ thermal conductivity for a given w/c ratio. Charles K. Kankam (2017) showed that blending sand and quarry dust produces concrete of enhanced mechanical properties. Malpani et. al (2014) observed that mix containing $40 \%$ sand, $40 \%$ marble sludge powder, $20 \%$ quarry rock dust had the best compressive strength. Chandana Sukesh, (2013) showed that replacement of sand with quarry dust improved compressive strength of concrete. Hameed \& Sakar, (2009) substituted sand with 50\% quarry stone dust and showed that 7 days and 28 days compressive strength of green concrete was $6.49 \%$ and $9.49 \%$ higher than controlled concrete respectively. Similarly the 7 days and 28 days split tensile strength of green concrete was 14.62 and $8.66 \%$ which were higher than controlled concrete respectively.

Talah et al (2015),found effective use of marble powder as sand substitute (15\%) without any decrease in strength of high performance concrete. Also, oxygen and chloride permeability confirmed the high durability of concrete. Er. Raj P. Singh Kushwah et al (2015) showed that marble slurry can be used as a filler material, replacing sand up to $30 \%$, without compromising strength of mortar and concrete. . Gulden Cagin Ulubeylia (2016) found out that the use of waste marble as an admixture material or aggregate in the conventional or self-compacting concrete mix can improve durability properties of the concrete such as water absorption, permeability, resistance of chloride penetration and sulphate attack. Gulden Cagin Ulubeylia (2015), showed that the use of waste marble in the conventional concrete mix can improve some properties of the hardened concrete. Silva, D. et al. (2014), showed that marble powder at $0,20,50$, and $100 \%$ sand substitute negatively affected workability and strength properties of concrete. Sounthararajan et al. (2013) found that $10 \%$ sand replacement with marble powder as optimum percent for enhanced mechanical strengths in concrete and workability decreased with increase in marble powder content. They also found that higher replacement of sand with marble powder is feasible for M30 concrete but 
not for higher strength concrete. Rai, B., Khan, N.H., Abhishek, K., Rushad, T., Duggal S.K, (2011), found better compressive and flexural strength of concrete by incorporating marble powder as partial sand substitute. Corinaldesi et al. (2010), found that at same workability, marble powder showed high strength at $10 \%$ sand substitution.

This research aims at utilization of waste marble powder and quarry dust in concrete as partial replacement of sand.

In this study, the laboratory tests for characterization of materials i.e. quarry dust and marble powder and determined their properties e.g. gradation, specific gravity and water absorption were conducted. Both cylinders and prisms were casted and tested. Sand was replaced by waste materials, Marble powder and Quarry dust from $12.5 \%$ to $50 \%$. ASTM standards were followed to determine fresh as well as hardened concrete properties such as workability, density, compressive strength, splitting tensile strength and flexural strength. Observations and results were recorded, compiled, interpreted and compared. Cost estimate and feasibility of Quarry Dust and Marble Powder as a replacement of sand has been evaluated for use in concrete.

\section{EXPERIMENTAL PROGRAM}

\subsection{Materials}

Ordinary Portland cement Type-1 conforming to ASTM C-150 requirements with blain fineness of $3090 \mathrm{~cm}^{2} / \mathrm{gm}$ was used as hydraulic binder. Table- 1 shows the comparison of properties of aggregates. Quarry dust and marble powder having maximum size of $4.75 \mathrm{~mm}$ and $2.38 \mathrm{~mm}$ respectively were used as partial replacements of sand. Figure 1 shows gradation of constituent materials. Table- 2 shows the results of chemical analysis of cement, marble powder and quarry dust.

Table- 1: Comparison of Properties of Aggregates

\begin{tabular}{|c|l|c|c|c|}
\hline Sr. & Material & $\begin{array}{c}\text { Fineness } \\
\text { Modulus }\end{array}$ & Sp. Gravity & $\begin{array}{c}\text { Water Absorption } \\
\text { (Vol \%) }\end{array}$ \\
\hline 1. & Coarse Aggregate & 7.0 & 2.50 & 0.96 \\
\hline 2. & Sand (Ravi) & 2.23 & 2.67 & 1.3 \\
\hline 3. & Marble Powder & 1.20 & 3.10 & 1.6 \\
\hline 4. & Quarry Dust & 3.16 & 2.15 & 1.4 \\
\hline
\end{tabular}




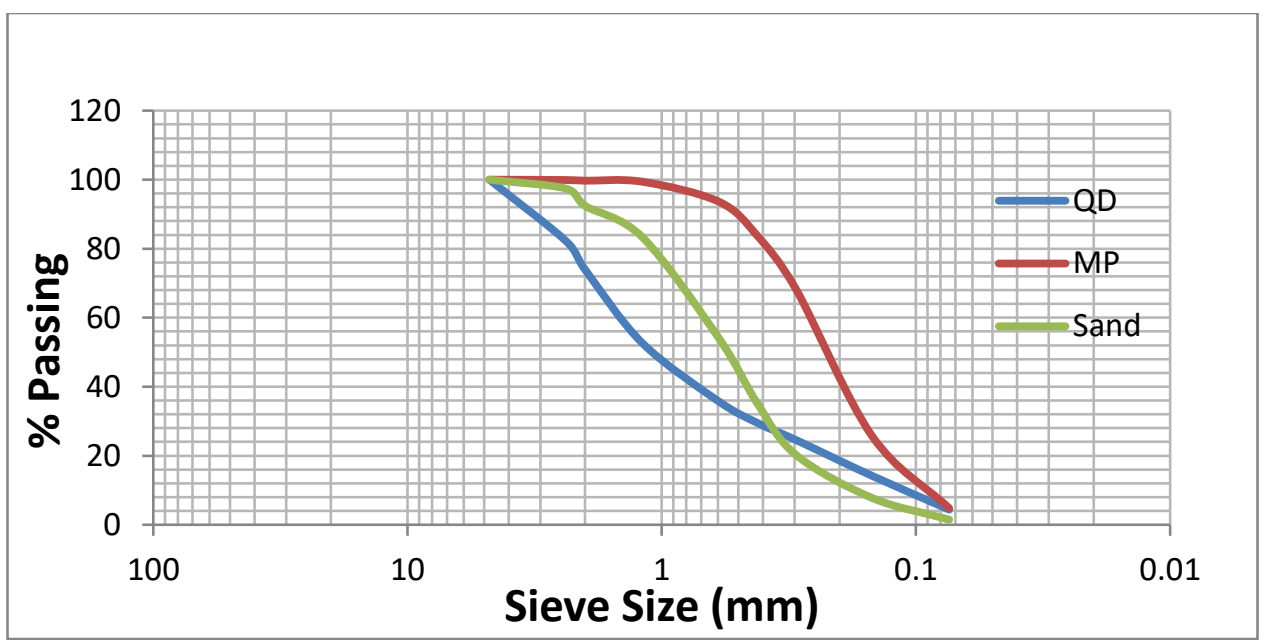

Figure- 1: Gradation of Constituent Materials

Table-2: Chemical Composition (Cement, Sand, Marble Powder and Quarry Dust)

\begin{tabular}{|l|l|c|c|c|c|}
\hline Sr. & Element & Cement (\%) & Sand (\%) & Marble Powder (\%) & Quarry Dust (\%) \\
\hline $\mathbf{1 .}$ & $\mathrm{CaO}$ & 62.13 & 3.21 & 42.98 & 4.83 \\
\hline $\mathbf{2 .}$ & $\mathrm{MgO}$ & 2.29 & 0.77 & 2.12 & 2.56 \\
\hline 3. & $\mathrm{SiO}_{2}$ & 20.25 & 80.78 & 12.20 & 62.48 \\
\hline $\mathbf{4 .}$ & $\mathrm{SO}_{3}$ & 2.57 & -- & 2.25 & 2.15 \\
\hline $\mathbf{5 .}$ & $\mathrm{Al}_{2} \mathrm{O}_{3}$ & 5.05 & 10.52 & 0.60 & 18.72 \\
\hline $\mathbf{6 .}$ & $\mathrm{Fe}_{2} \mathrm{O}_{3}$ & 3.13 & 1.75 & 0.19 & 6.54 \\
\hline 7. & $\mathrm{L.O.I}$ & 4.42 & 0.37 & 36.95 & 0.48 \\
\hline $\mathbf{8 .}$ & $\mathrm{K}_{2} \mathrm{O}$ & 0.74 & 1.23 & 0.435 & 3.18 \\
\hline 9. & $\mathrm{Na}_{2} \mathrm{O}$ & 0.24 & 1.37 & 0.526 & --- \\
\hline $\mathbf{1 0 .}$ & $\mathrm{TiO}_{2}$ & --- & --- & --- & 1.21 \\
\hline
\end{tabular}

\subsection{Experimental Methodology}

Trial mixes at $w / c$ ratios of $0.45,0.5,0.55$ and 0.60 were prepared in order to decide an appropriate $\mathrm{w} / \mathrm{c}$ ratio and a workable mix, without any bleeding and segregation and w/c of 0.55 was selected. Mix ratio 1:2:3 was employed. Marble powder and quarry dust were utilized at the rate of $12.5 \%, 25 \%$ and $50 \%$ as individual replacement for sand and 25\% \& 50\% as combined replacement in equal proportions and 9 mix (as shown in Table-3) were prepared. For compressive strength and split cylinder tensile strength test, cylinders of $150 \times 300 \mathrm{~mm}$ and for flexural strength test prisms of 100x100x500 mm size were casted and tested at 28 days (Figure 2).

Slump test was carried out for each mix as per ASTM C143 / C143M. Compressive strength and split cylinder tensile strength tests were conducted as per ASTM C39 / C39M and C496 Standard methods respectively. Flexural strength tests was carried out as per ASTM C 293 Standard using Universal Testing Machine of $1000 \mathrm{KN}$ capacity. 


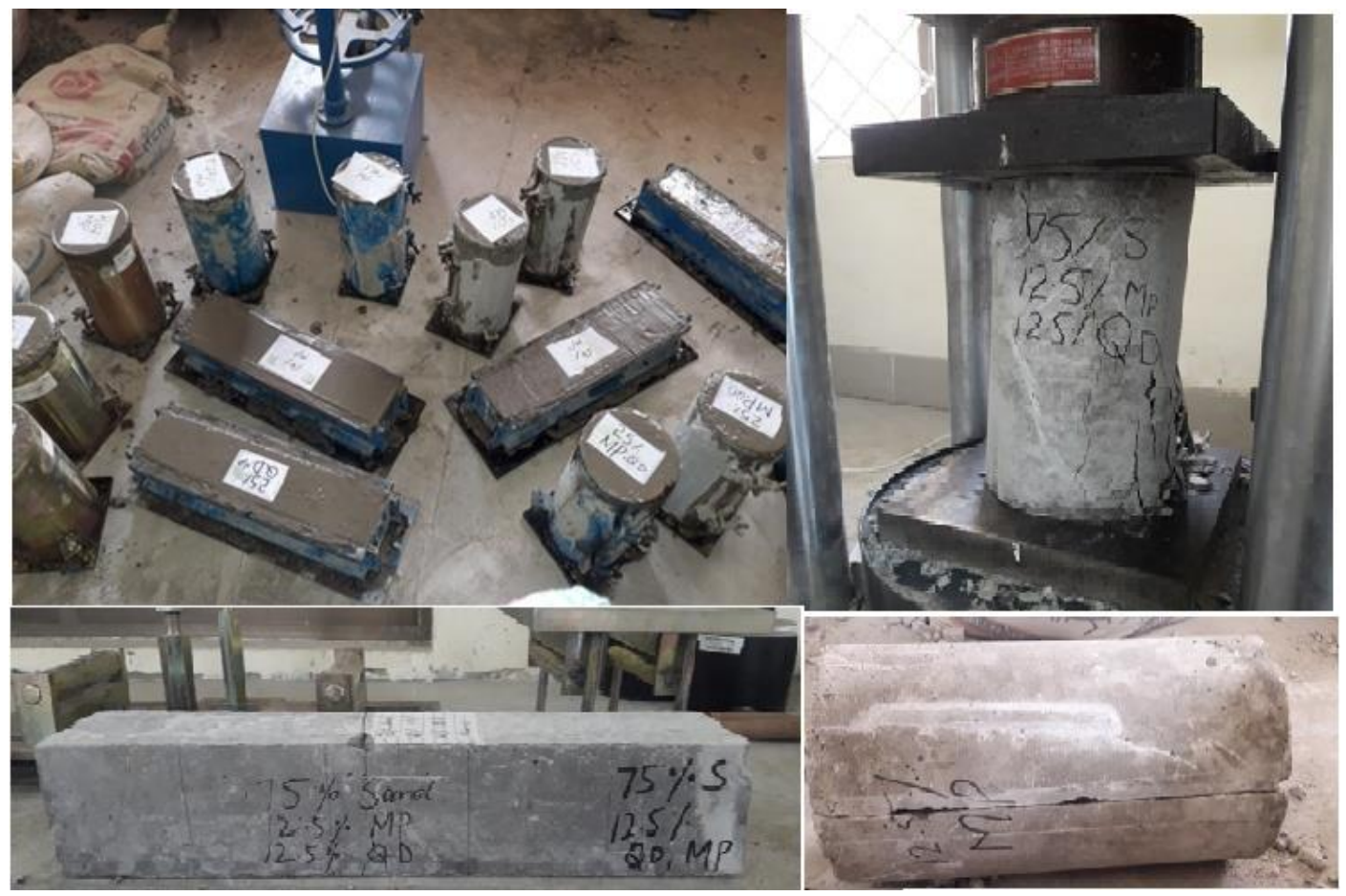

Figure-2: Experimentation

\section{RESULTS}

Properties of fresh and hardened concrete were affected by replacement of sand with marble powder and quarry dust.

Figure-3 indicates that slump values (workability) increased with Quarry Dust amount and reduced with Marble Powder amount. Slump values of concrete having combined replacement of Marble Powder and Quarry Dust both were moderately improved.

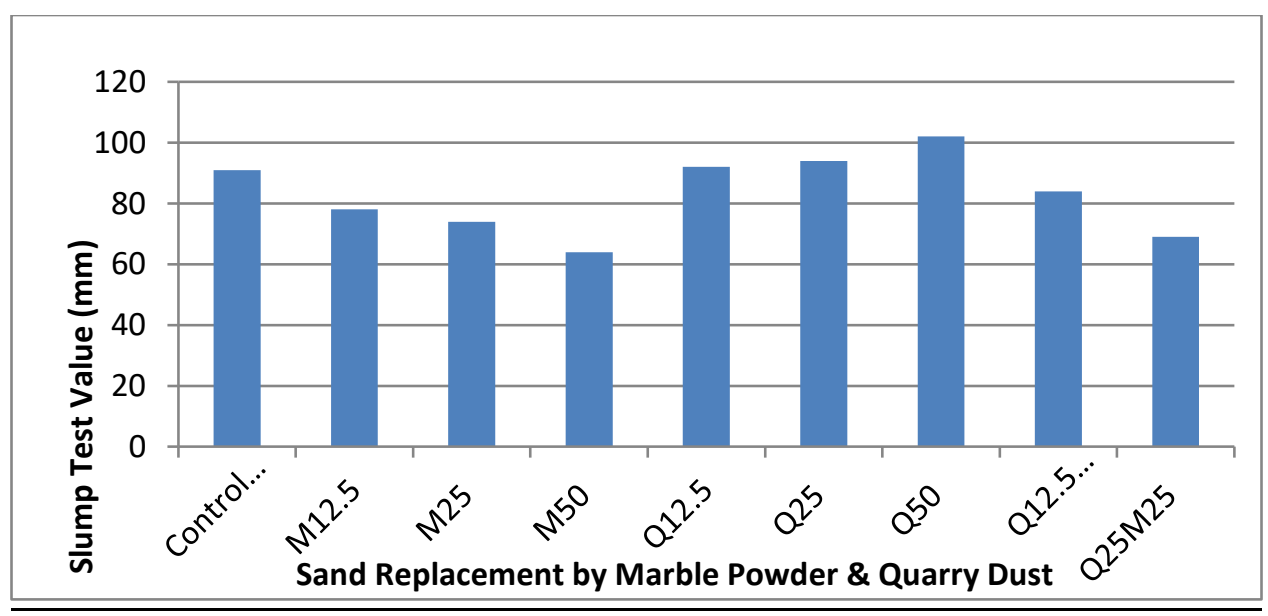

Figure-3: Slump Test Values 
Figure-4 shows that compressive strength increased by replacement of sand with Marble Powder and Quarry Dust up to $12.5 \%$ then decreased with further replacement. The combined replacement of these two materials up to $25 \%(12.5 \% \mathrm{MP}+12.5 \% \mathrm{QD})$ has improved the compressive strengths. M12.5 and Q12.5 have strength $25.93 \%$ and $17.73 \%$ respectively more than control sample. Minimum value of compressive strength was for Q25 (i.e. $7.46 \%$ less than control specimen).

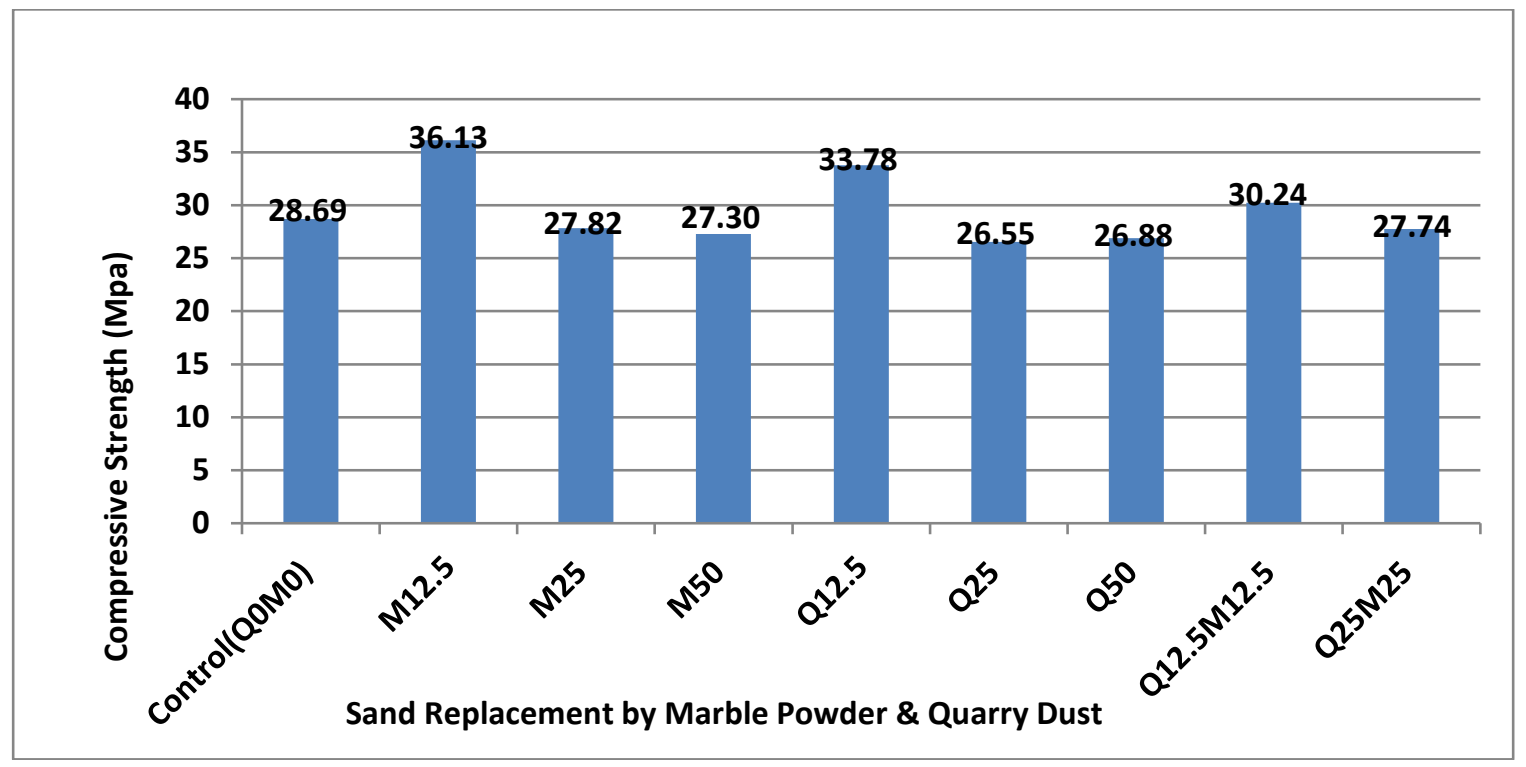

Figure-4: Compressive Strength

Figure-5 reveals that Tensile strength of concrete exhibited same trend as that of compressive strength i.e. it improved with replacement of sand with Marble Powder and Quarry Dust up to $12.5 \%$ and combined replacement of these materials up to $25 \%$ $(12.5 \% \mathrm{MP}+12.5 \% \mathrm{QD})$; however, it decreased with further replacement. Maximum value of tensile strength was 5.70 MPa for M12.5, being $27.94 \%$ more than control concrete. Q12.5 and Q12.5M12.5 have strengths $8.33 \%$ and $8.63 \%$ respectively more than control concrete. 


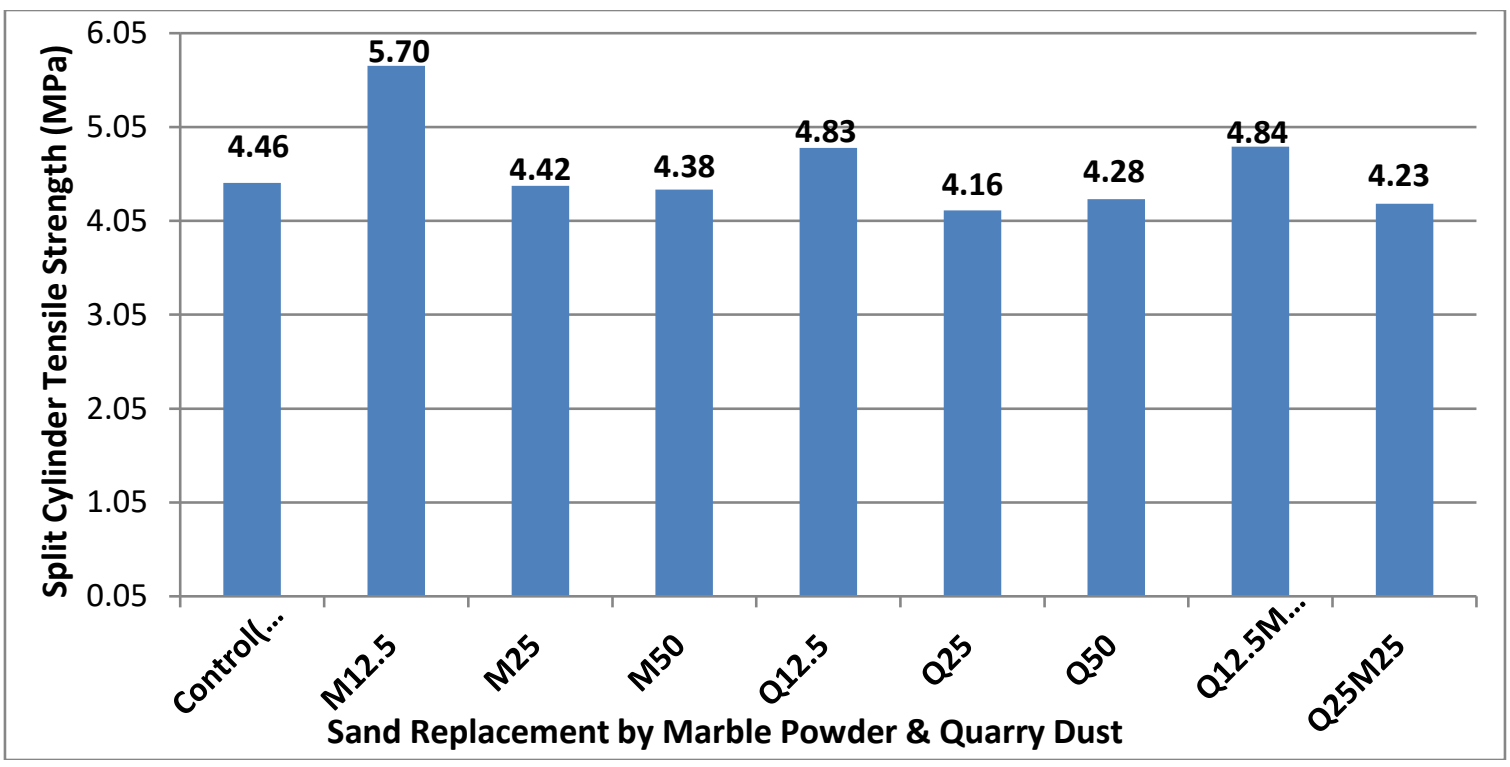

Figure-5: Indirect Tensile Strength

Figure-6 indicates that Flexural strength of concrete also improved due to replacement of Marble Powder and Quarry Dust up to $12.5 \%$ and then decreased. Maximum value of Flexural strength obtained was for M12.5 sample which was $40.9 \%$ more than that of control sample. Flexural strength of Q 12.5 sample was $28 \%$ more than control concrete.

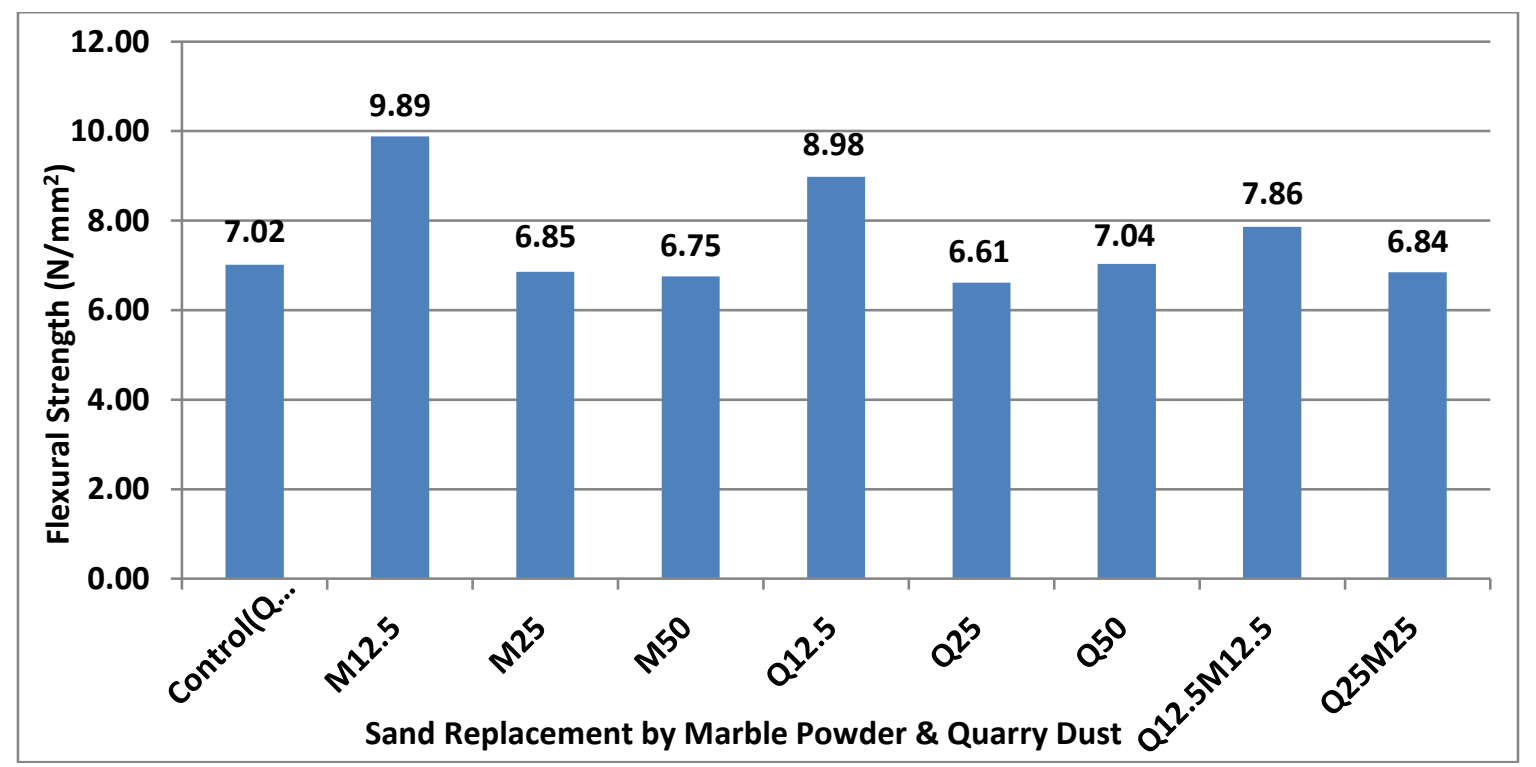

Figure-6: Flexural Strength

Relative cost of marble powder, quarry dust and sand vary from region to region depending upon their availability. The cost may include transportation charges additional nominal cost of processing/drying. Table-4 shows comparison of cost of 
production of $100 \mathrm{~m}^{3}$ concrete in Pakistan between conventional concrete and those in which sand has been partially replaced by marble powder and quarry dust on the basis of at source material cost. Cost of production of $100 \mathrm{~m}^{3}$ conventional, M50, Q50 concrete is USD 3453, USD 3391 and USD 3398 respectively. Therefore, incorporation of marble powder and quarry dust in place of sand produces moderately economical concrete

Table-4: Mix Proportions of Concrete Mix and Cost Estimate.

\begin{tabular}{|c|c|c|c|c|c|c|c|}
\hline Mix & $\mathbf{w} / \mathbf{c}$ & $\begin{array}{c}\text { Cement } \\
(\mathrm{Kg})\end{array}$ & $\begin{array}{l}\text { Sand } \\
(\mathrm{Kg})\end{array}$ & $\begin{array}{c}\text { Aggregate } \\
(\mathbf{K g})\end{array}$ & $\begin{array}{l}\text { QD } \\
(\mathbf{K g})\end{array}$ & $\begin{array}{c}\text { MP } \\
(\mathrm{Kg})\end{array}$ & \multirow{3}{*}{$\begin{array}{c}\begin{array}{c}\text { Cost } \\
\text { (USD per } \\
\mathbf{1 0 0}^{\mathbf{3}} \text { ) }\end{array} \\
3453 \\
\end{array}$} \\
\hline & & \multicolumn{5}{|c|}{ Quantity of concrete $=1 \mathbf{m}^{3}$} & \\
\hline $\begin{array}{l}\text { Control } \\
\text { (Q0M0) }\end{array}$ & \multirow{9}{*}{0.55} & 327 & 654 & 981 & 0 & 0 & \\
\hline M12.5 & & 327 & 572 & 981 & 0 & 82 & 3438 \\
\hline M25 & & 327 & 490 & 981 & 0 & 164 & 3422 \\
\hline M50 & & 327 & 327 & 981 & 0 & 327 & 3391 \\
\hline Q12.5 & & 327 & 572 & 981 & 82 & 0 & 3439 \\
\hline Q25 & & 327 & 490 & 981 & 164 & 0 & 3425 \\
\hline Q50 & & 327 & 327 & 981 & 327 & 0 & 3398 \\
\hline Q12.5M12.5 & & 327 & 490 & 981 & 82 & 82 & 3424 \\
\hline $\mathrm{Q} 25 \mathrm{M} 25$ & & 327 & 327 & 981 & 163.5 & 163.5 & 3394 \\
\hline
\end{tabular}

Cement $=0.0916(\mathrm{USD} / \mathrm{KG})$, Coarse Agg. $=0.0032(\mathrm{USD} / \mathrm{Kg})$, Sand $=.0022$

$\mathrm{USD} / \mathrm{Kg}$ ),

Marble Powder $(\mathrm{MP})=0.0003(\mathrm{USD} / \mathrm{Kg})$, Quarry Dust $(\mathrm{QD})=0.0005(\mathrm{USD} / \mathrm{Kg})$

\section{DISCUSSION}

Decrease in slump value due to marble powder may be attributed to its finer particles, having larger surface area and hence increased water demand and vice versa may be true for quarry dust. Decreased workability may be due to higher water demand of MP due to its fineness. Improved workability may be due to less water demand of QD because of lower fineness.

Percentage differences of strength from conventional concrete are shown in Table-3.

Table-3: Percentage Difference of Strength Values ("++" indicates increase in strength while "-" indicates decrease).

\begin{tabular}{|l|c|c|c|}
\hline Specimen ID & $\begin{array}{c}\text { Compressive } \\
\text { Strength (MPa) }\end{array}$ & $\begin{array}{c}\text { Indirect Tensile } \\
\text { Strength (MPa) }\end{array}$ & $\begin{array}{c}\text { Flexural Strength } \\
\text { (MPa) }\end{array}$ \\
\hline Control(Q0M0) & ---- & --- & --- \\
\hline M12.5 & +25.93 & +27.94 & +40.91 \\
\hline M25 & -3.04 & -0.73 & -2.30 \\
\hline M50 & -4.86 & -1.64 & -3.74 \\
\hline Q12.5 & +17.73 & +8.33 & +28.04 \\
\hline Q25 & -7.46 & -6.60 & -5.75 \\
\hline
\end{tabular}




\begin{tabular}{|l|c|c|c|}
\hline Q50 & -6.32 & -3.93 & 0.29 \\
\hline Q12.5M12.5 & +5.39 & +8.63 & +12.07 \\
\hline Q25M25 & -3.31 & -5.00 & -2.44 \\
\hline
\end{tabular}

Generally, results of all strength tests exhibited similar trend: Strength increased for $12.5 \%$ replacement of sand with marble powder and quarry dust, however with further replacement of sand strength values decreased both for marble powder and quarry dust. Reason for improvement of strength properties can be attributed to filler effect of marble powder and better workability of quarry dust mixes. Marble powder, due to its finer particle size, has filler effects and helps in better packing and production of more dense mass of concrete with better strength properties. Very fine marble powder with high $\mathrm{CaO}$ content and surface area shows higher strength at $12.5 \%$. After this optimum percentage more water is required due to adsorption for higher surface area of Marble powder hence the strength is decreased. Additionally increase of marble powder quantity beyond $12.5 \%$ disturbs the proportion between finer and coarser particles and thus excess of fine particles causes decrease in strength, as is evident from comparison of M25 and M50 sample. Quarry dust, due to its relatively larger particle size and less water absorption, produces more workable mix with better compaction properties (dense mass) having improved strength. As replacement of quarry dust increases, demand of water decreases than control mix. Therefore, replacement of quarry dust beyond a certain quantity, water remains in excess (since w/c ratio is constant) and this excess water causes in decrease in strength.

Incorporation of marble powder and quarry dust in place of sand produces moderately economical concrete with acceptable workability and mechanical strengths.

\section{CONCLUSIONS}

Based on this research, following conclusions can be drawn:

- Workability of the mix is reduced due to replacement of sand with Marble Powder. Decreased consistency of the concrete mix can be attributed to higher water demand of Marble Powder due to its fineness (higher surface area). Workability of the mix improved due to replacement of sand with Quarry Dust. Improved consistency may be due to less water demand of Quarry Dust because of lower fineness.

- Compressive strength increased by replacement of sand with Marble Powder and Quarry Dust up to $12.5 \%$ then decreased with further replacement. Also, combined replacement of these two materials up to $25 \%(12.5 \%$ $\mathrm{MP}+12.5 \% \mathrm{QD})$ has improved results of compressive strength, Q12.5M12.5 specimen showed compressive strength $5.39 \%$ more than control specimen value. Strengths are increased up to optimum percentages, but decreases after optimal value. The reason for high strength up to optimal value is chemical composition ( $\mathrm{CaO}$ content), surface area, filling effect, nucleation effect of sand replacement materials. After optimal values, water requirement is increased and improper packing may occur, hence strength is decreased. 
- Tensile strength of concrete exhibited same trend as that of compressive strength i.e. it improved with replacement of sand by Marble Powder and Quarry Dust up to $12.5 \%$ and combined replacement of these materials up to $25 \%(12.5 \% \mathrm{MP}+12.5 \% \mathrm{QD})$.

- Flexural strength of concrete also improved due to replacement of Marble Powder and Quarry Dust up to $12.5 \%$ and then decreased. Maximum value of Flexural strength obtained was for M12.5 specimen, $40.9 \%$ more than that of control specimen.

- Generally, results of all strength tests exhibited similar trend: M12.5, Q12.5 and Q12.5 M12.5 specimens have strengths more than control specimen values and all other specimens have strengths less than control specimen with Q25specimen having minimum strength values.

- Both quarry dust and marble powder can be used up to $25 \%$ each separately and $50 \%(25 \% \mathrm{Q}+25 \% \mathrm{M})$ in combined form in concrete production without much compromise in strengths and workability. Thus these waste materials can effectively replace the natural sand. Thus in the areas with high percentages of wasted Quarry dust and Marble powder, the heap depositing and associated hazardous environmental problem is resolved by using wastes in concrete. At the same time the natural sand source depletion rate can be decreased.

- Cost analysis shows that concrete having replacement of marble powder and quarry dust is economical than conventional concrete. Cost of production of $100 \mathrm{~m}^{3}$ conventional, M50, Q50 concrete is USD 3453, USD 3391 and USD 3398 respectively.

- It is, therefore, feasible to utilize quarry dust and marble powder in concrete production as partial replacement of fine aggregate. It improves mechanical properties of concrete and, helps to solve the environmental, economic and material conservation or ecological problems associated with concrete production.

\section{ACKNOWLEDGEMENT}

Thanks to UET Lahore for providing research grant to postgraduate student.

\section{REFERENCES}

Mater, Concrete International Magazine - American Concrete Institute. Corinaldesi, V., Moriconi, G., and Taurun, R. M. (2010). " Characterization of marble powder for his use in mortar and concrete". Constr. Build. 24(1), pp.113117.

Kushwah, R.P.S., Sharma, I.C. and Chaurasia, P.B.L., 2015. Utilization of marble slurry in cement concrete replacing fine aggregate. Am. J. Eng. Res, 4(1), pp.5558 . 
Lim, S.K., Tan, C.S., Li, B., Ling, T.C., Hossain, M.U. and Poon, C.S., 2017. Utilizing high volumes quarry wastes in the production of lightweight foamed concrete. Construction and Building Materials, 151, pp.441-448.

Mehta, K.P., 2001. Reducing the environmental impact of concrete. Concrete international, 23(10), pp.61-66.

Prabhu, G.G., Hyun, J.H. and Kim, Y.Y., 2014. Effects of foundry sand as a fine aggregate in concrete production. Construction and Building Materials, 70, pp.514521.

Kafi, M.A., Sadeghi-Nik, A., Bahari, A., Sadeghi-Nik, A. and Mirshafiei, E., 2016. Microstructural characterization and mechanical properties of cementitious mortar containing montmorillonite nanoparticles. Journal of Materials in Civil Engineering, 28(12), p.04016155.

Alyamaç, K.E. and İnce, R., 2007. Study on the usability of waste marble mud in self-compacting concrete as a powder material. In Proceedings of TÇMB 3rd International Symposium (pp. 821-832).

http://www.apmia.org.pk/.All Pakistan Marble Industry Association.

Masroor Ahmed Korai (2010)." A Report on Marble \& Granite. Trade Development Authority of Pakistan", Minerals \& Metals Division

Sarsby, R.W. and Meggyes, T. eds., 2001. The Exploitation of Natural Resources and the Consequences: The Proceedings of Green 3: the 3rd International Symposium on Geotechnics Related to the European Environment Held in Berlin, June 2000. Thomas Telford.

Kankam, C.K., Meisuh, B.K., Sossou, G. and Buabin, T.K., 2017. Stress-strain characteristics of concrete containing quarry rock dust as partial replacement of sand. Case studies in construction materials, 7, pp.66-72.

Gondal, M.M.I., AHSAN, N. and JAVID, A.Z., 2009. Engineering properties of potential aggregate resources from eastern and central Salt Range, Pakistan. Geological Bulletin of Punjab University, 44, pp.97-103.

Gauhar Sabih, S. Muhammad Jamil (2011).” Effects of Gradation of Various Sand Deposits of Pakistan on Strength of Hardened Concrete". First International Conference on Geotechnique, Construction Materials and Environment, Mie, Japan, Nov.21-23, 2011, ISBN: 978-4-9905958-0-7 C3051 
Priyatham, B.P.R.V.S., Chaitanya, D.V.S.K. and Dash, B., 2017. Experimental Study on Partial Replacement of Cement with Marble Powder And Fine Aggregate with Quarry Dust. Technology, 8(6), pp.774-781.

Rai, B., Khan Naushad, H., Kr, A., TabinRushad, S. and Duggal, S.K., 2011. The effect of using marble powder and granules as constituents of fines in mortar or concrete. International journal of civil and structural engineering, 1(4), p.0.

Chandra, S., 1996. Waste materials used in concrete manufacturing. Elsevier.

Shirule, P.A., Rahman, A. and Gupta, R.D., 2012. Partial replacement of cement with marble dust powder. International Journal of Advanced Engineering Research and Studies, 1(3), pp.175-177.

Silva, D., Gameiro, F. and de Brito, J., 2013. Mechanical properties of structural concrete containing fine aggregates from waste generated by the marble quarrying industry. Journal of materials in civil engineering, 26(6), p.04014008.

Sounthararajan, V.M. and Sivakumar, A., 2013. Effect of the lime content in marble powder for producing high strength concrete. ARPN Journal of Engineering and Applied Sciences, 8(4), pp.260-264.

Talah, A., Kharchi, F. and Chaid, R., 2015. Influence of marble powder on high performance concrete behavior. Procedia Engineering, 114, pp.685-690. 